\title{
Antimicrobial Activity of Quinoxaline Derivatives
}

\author{
GAURI GUPTA* and PREETI VERMA \\ Pharmacy Academy, IFTM University, Moradabad, UP, India \\ gaurigupta06@gmail.com
}

Received 5 January 2014 / Accepted 24 January 2014

\begin{abstract}
Different types of quinoxaline derivatives show antimicrobial activity. Quinoxalines, also named as Benzopyrazines, having a nitrogen ring, in organic chemistry is a hetrocyclic compounds containing a ring complex made up of a benzene ring and a pyrazine ring. To modify in their nucleus, they form different derivatives of quinoxaline which contains antimicrobial activity. To modify in their structure shows a wide variety of new therapeutic agents having better potency and lesser toxicity. This article is shows to review history, chemistry, synthesis and the derivatives of quinoxaline which shows antimicrobial activity.
\end{abstract}

Keyword: Quinoxaline, Benzopyrazine, Antimicrobial activity

\section{Introduction}

Quinoxalines, also called a Benzopyrazines, in organic chemistry, it is a hetrocyclic compounds containing a ring complex made up of a benzene ring and a pyrazine ring, isomeric with the cinnolenes, phthalazines and quinazolines ${ }^{1}$. Quinoxaline derivatives exhibit a broad spectrum of biological activity such as antibacterial ${ }^{2-4}$, antifungal ${ }^{5,6}$, antiviral ${ }^{7}$, anticancer ${ }^{8}$, anti-tubercular ${ }^{9}$, antimalarial $^{10}$ and anti-inflammatory ${ }^{11}$. Quinoxaline is well known for its broad coverage in the field of medicine as well as for its application in the pharmaceuticals. Quinoxalines constitute an important class of compounds, of which some analog has synthesized and evaluated for antimicrobial activity. Many possess different biological activity such as insecticides, fungicides, herbicides, anthelmintic and antiviral. Among the various classes of nitrogen containing heterocyclic compounds, a quinoxaline derivative constitutes synthetic libraries for drug discovery. Synthetic quinoxaline nucleus is the part of a number of antibiotics which are known to inhibit the growth of gram positive bacteria and are also active agents to treat tuberculosis ${ }^{12,13}$. Recent studies has shown that some quinoxaline derivatives inhibit selectively the plateletderived growth factor (PDGF) receptor kinase, PDGF- dependent DNA synthesis in cell lines ${ }^{14}$ and it inhibit the human cancer cell lines ${ }^{15}$. On the other hand, a quinonimine system such as napthooxazinoquin-oxalinone derivative ${ }^{16}$, is of interest because this system constitutes the structure of several antitumor antibiotics such as actinomycin $\mathrm{D}^{17}$, questiomycin $\mathrm{A}^{18}$ and glycosyl questiomycin $^{19}$. Also, among the wide variety of heterocycles that have been explored for the viral and antifungal activities of developing pharmaceutically important molecules ${ }^{20}$. Cyanopyridines $^{21,22}$ and isoxazoles ${ }^{23-25}$ have been similarly investigated. 


\section{Chemistry}

Quinoxaline is a weak, basic, bicyclic compound commonly called 1,4- diazanaphthalene or benzopyrazine containing a fused benzene and pyrazine ring.

Quinoxaline is a low melting solid, having a melting point $20-30{ }^{\circ} \mathrm{C}$. They are miscible with water. It is white crystalline powders containing a molecular formula $\mathrm{C}_{8} \mathrm{H}_{6} \mathrm{~N}_{2}$. The molecular weight of quinoxaline contains $130.1466^{26}$. Quinoxaline are formed by condensing of orthodiamine with 1,2 diketone $\mathrm{d}^{\mathrm{s} 27}$. Quinoxaline itself prepared by the reaction of $o$-phenyldiamine and glyxol ${ }^{28}$. Natural products containing quinoxaline ring are rare and can be easily prepared or synthesized. Quinoxaline itself prepared by the condensation of $o$-phenylene diamine with glyoxal sodium bisulphite in $85-90 \% /$ yield $^{29}$.<smiles>Nc1ccccc1N</smiles>

benzene-1,2-diamine<smiles>CC(=O)C(C)=O</smiles>

butane-2,3-dione

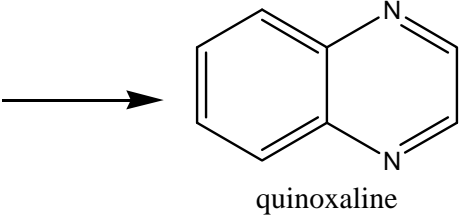

Scheme 1. Synthesis of Quinoxaline

2-Methyl quinoxaline has been prepared by the reaction of $o$-phenyldiamine and pyruvaldehyde $^{30}$.<smiles>Nc1ccccc1N</smiles>

o-phenyldiamine

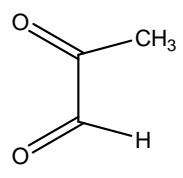

pyruvaldehyde<smiles>Cc1cnc2ccccc2n1</smiles>

2-methyl quinoxaline

Scheme 2. Synthesis of 2-methylQuinoxaline

Taylor recently reported that 1-(p-tolylsulfonyl)-2-phenloxirane, obtained from the condensation of chloromethyl $p$-tosylsulfone with benzaldehyde, on reaction with $o$-phenylenediamine yields 2-phenylquinoxaline with good yield ${ }^{31}$.

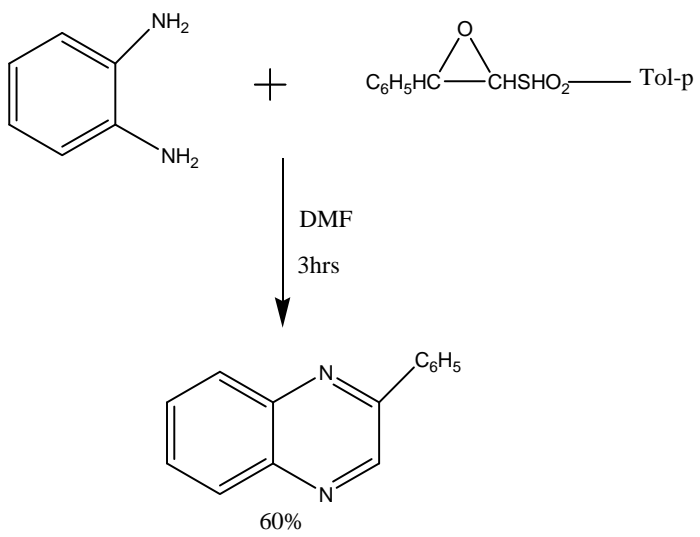

Scheme 3. Synthesis of 1-(p-tolysulphonyl)-2-phenloxirane

Quinoxaline forms salt with acids. Nitration occurs only under forcing conditions (conc. $\mathrm{HNO}_{3}$, Oleum, $90{ }^{\circ} \mathrm{C}$ ) to give 5-nitroquinoxaline (1.5\%) and 5,7-dinitro-quinoxaline (95\%) 
<smiles></smiles>

Scheme 4. Synthesis of 5-nitroquinoxalineand 5,7dinitroquinoxaline

Oxidation of quinoxaline results in the formation of the product and depending on the nature of the oxidizing agent employed with alkaline pot. Permanganate pyrazine. 2,3-Dicarboxylic acid is formed, while with per acid quinoxaline di- $N$-oxide results ${ }^{33}$.

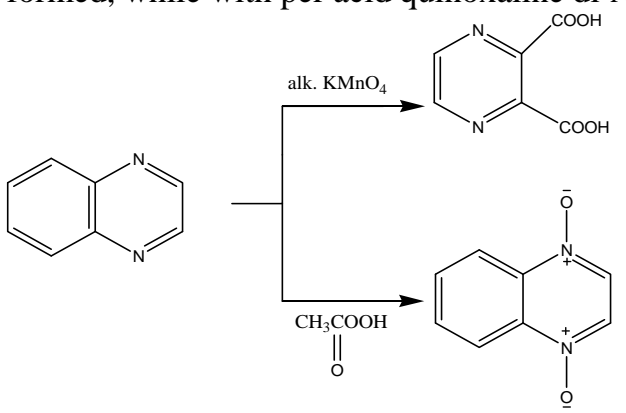

2-Hydroxy quinoxaline exists in tautomeric form as<smiles>O=c1cnc2ccccc2[nH]1</smiles>

Scheme 5. Tautomeric form of Quinoxaline

The parent substance of the group, quinoxaline, resulting when glyoxal in condensed, when substitution derivatives arise when a ketonic acids, a chlor ketones, an aldehyde alcohols and a ketone alcohols are used in place of diketones ${ }^{34}$.

The fusion of one or two benzene rings in quinoxaline and phenazine increases the number of resonance structure which are available to these systems. Quinoxaline possess a dipole moment of zero ${ }^{35}$. A number of simple variations in the diamine appear to well work. Thus replacement of the dialdehyde with an - halogenoketone results in the formation of 2- substituted quinoxaline has been prepared in this manner from phenachloride and $o$-phenylenediamine.

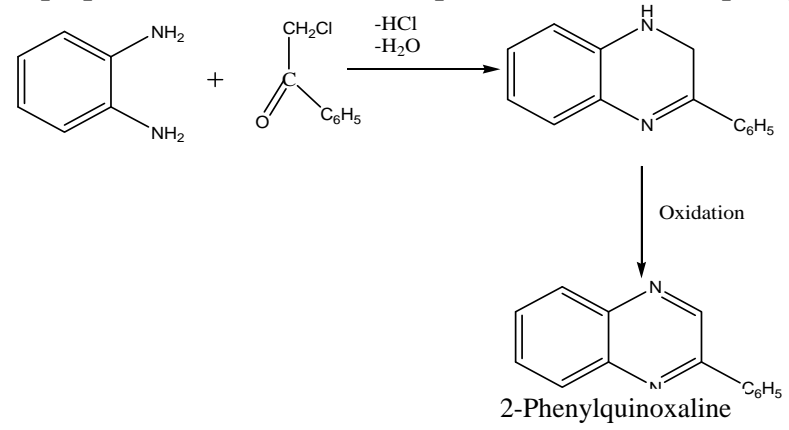

Scheme 6. Synthesis of 2-phenylquinoxaline

\section{Antimicrobial activity}

1) $O$-phenylenediamine is reacted with 5-bromo Isatin and the resultant compound is reacted with various aromatic and aliphatic amines to form the 9-bromo- $\mathrm{N}$-substituted- $6 \mathrm{H}$ - indolo [2,3b] quinoxaline-3-sulfonamide derivatives of quinoxaline were evaluated with anti-microbial 
activity against a variety of bacterial strains (both Gram + ve and Gram -ve) and fungal strains and some of these compounds have shown significant antibacterial and antifungal activities ${ }^{36}$.<smiles>[R7]c1ccc(Br)cc1-c1cc(C(C)=O)ccc1N</smiles>

Scheme 7. 9-Bromo- $N$-substitute-6H-indolo [2,3-b] quinoxaline-3-sulfonamide

2) 1-(2-((2,3-Diphenylquinoxalin-6-yl)methyl)-6H-indolo[2,3-b]quinoxalin-6-yl)propan-2one is reacted with aromatic aldehyde in the presence of sodium hydroxide it gives 4-aryl-1(2-((2,3-diphenylquinoxalin-6-yl)methyl)-6H-indolo[2,3-b]quinoxalin-6-yl)but-3-en-2-one then it reacted with benzoic acid hydrazide in glacial acetic acid it gives (4,5- dihydro-5aryl-3-((2-((2,3-diphenylquinoxalin-6- yl)methyl)-6H-indolo[2,3-b]quinoxalin-6-yl)methyl) pyrazol-1-yl)phenyl) methanone. The entirecompound will show antimicrobial activity ${ }^{37}$.

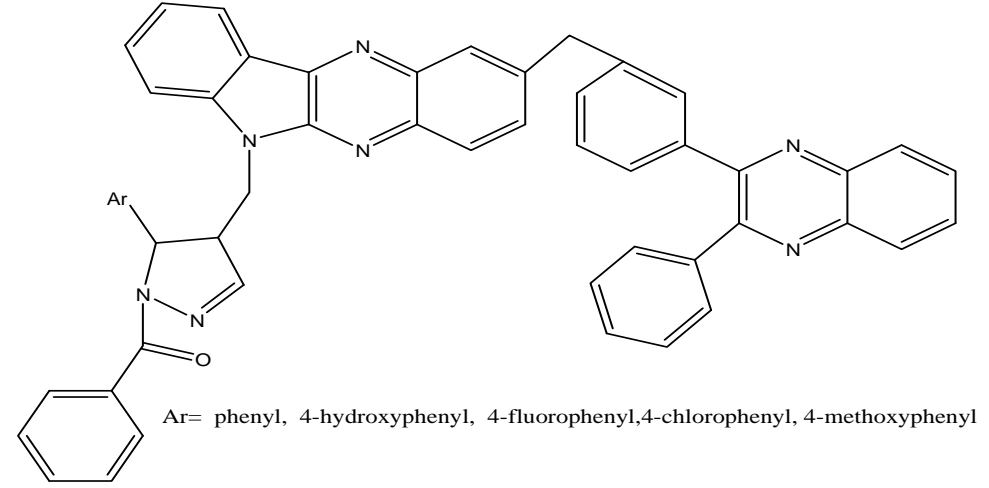

Scheme 8. 4,5-Dihydro-5-aryl-3-((2-((2,3-diphenylqunioxalin-6-yl)-6H-indolo[22,3-b] qunioxalin-6-yl) methyl) pyrazaol-1-yl)phenyl)methanone

3) o-Phenylenediamine was the starting material for the synthesis of 2,3-diphenyl quinoxaline. Different derivatives were prepared by replacing hydrogen at $6^{\text {th }}$ position of 2, 3-diphenyl quinoxaline by using different groups such as nitro, sulfonyl choride, sulfonic acid amide according to the literature. All compounds were synthesized in good yields and high purity. They were evaluated with anti-bacterial activity ${ }^{38}$.<smiles>O=S(=O)(Cl)c1ccc2nc(-c3ccccc3)c(-c3ccccc3)nc2c1</smiles>

2,3-diphenyl quinoxaline-6-sulfonyl chloride<smiles>NS(=O)(=O)c1ccc2nc(-c3ccccc3)c(-c3ccccc3)nc2c1</smiles>

2,3-diphenyl quinoxaline-6-sulfonic acid amide 
4) 6-Substituted quinoxalines and 7-substituted pyrido[2,3b]pyrazines were evaluated for their anti microbial activity ${ }^{39}$.<smiles>[R9]c1cnc2nc([R6])c([2H])nc2c1</smiles>

R1=H; R2=Ph, R1=H; R2=Me, R1=H; R2=Pyr, R1=Br; R2=Ph, R1=Br; R2=Me, R1=Br; R2=Pyr,

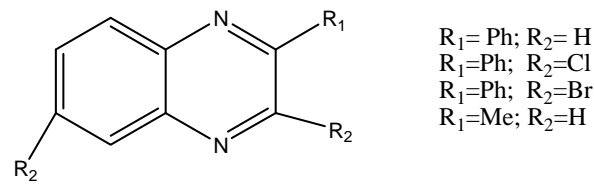

6-Sustituted quinoxalines

5) The 1,3-dipolar cyclo addition of 3-methylquinoxaline-2-thione and their $\mathrm{N}$-alkylated derivatives to diphenylnitrile imine is presented. Using this method, spiro[thiadiazolinequinoxaline] derivatives as biologically interesting compounds were produced in high to excellent yields.Antibacterial activity of the synthesized products has been studied ${ }^{40}$.<smiles>CCn1c(=S)c(C)nc2ccccc21</smiles>

$\mathrm{R}=\mathrm{H}$, Allyl, Ethyl<smiles>CCN1c2ccccc2N=C(C)C12SC(c1ccccc1)=NN2c1ccccc1</smiles>

6) The formation of $N, N$-disubstituted cyclohexane-1,2-diamine derivatives through reductive alkylation of 1,2-cyclohexanediamine with different aldehydes in presence of sodium cyanoborohydride. Fusion of compounds with diethyl oxalate affording the target compounds it possesses antimicrobial activity ${ }^{41}$.

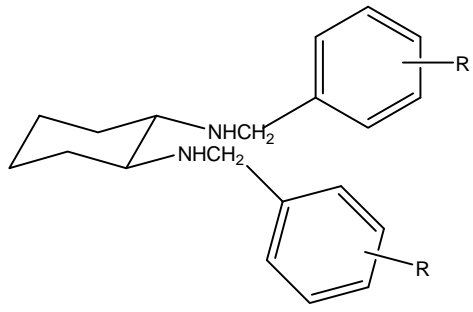

$\mathrm{R}=\mathrm{H}, \mathrm{p}-\mathrm{Br}, \mathrm{p}-\mathrm{Cl}, \mathrm{o}-\mathrm{Cl}, \mathrm{p}-\mathrm{CH}_{3}, \mathrm{p}-\mathrm{C}_{3} \mathrm{H}_{7}, \mathrm{p}-\mathrm{OCH}_{3}$

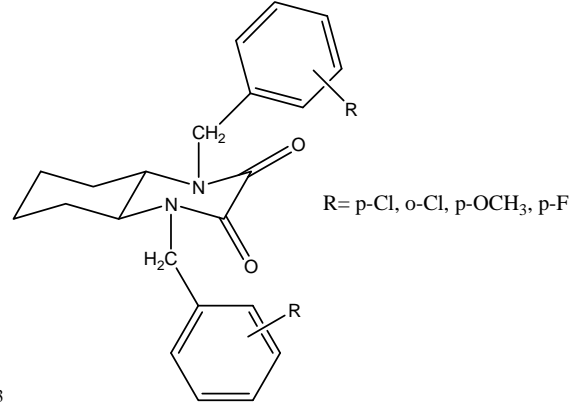

7) In an effort to develop potent anti-microbial agents, we have synthesized some substitutedquinoxalin-2(1H)-one derivatives by Phillip's condensation mechanism. Final derivatives were screened for their in vitro anti-bacterial activity against range of Gram positive and Gram negative and also for their anti-fungal activity against a strain of Candida albicans species ${ }^{42}$.<smiles>CC(C)/N=C\CNC1=Nc2ccccc2NC1</smiles>

$\mathrm{C}_{6} \mathrm{H}_{5}-\mathrm{CH}_{2} \mathrm{CH}=\mathrm{CH} \mathrm{CHO}$ III b $3 \mathrm{Cl}-\mathrm{C}_{6} \mathrm{H}_{4} \mathrm{CHO}$ $\mathrm{Ar}=\mathrm{III} \mathrm{c}\left(\mathrm{CH}_{3}\right)_{2} \mathrm{~N} \mathrm{C}_{6} \mathrm{H}_{4} \mathrm{CHO}$ III d 3,4 Cl- $\mathrm{C}_{6} \mathrm{H}_{3} \mathrm{CHO}$ III e $\mathrm{OH} \mathrm{Cl} \mathrm{H}_{2} \mathrm{CHO}$

3-[(2-\{(E)-(substituted phenyl) methyliden]amino $\}$ ethyl)amino]quinoxalin-2(1H)-one 
8) Starting compound quinoxaline-1,2-diol was prepared from o-phenylenediamine and diethyloxalate upon refluxing for $1 \mathrm{~h}$ in single step. The quinoxaline-1,2-diol was refluxed for 90 min with phosphorous oxy chloride, to furnish 2,3-dichloroquinoxaline. Further 3-chloro- 2hydrzinoquinoxaline was prepared by reaction of 2,3-dichloroquinoxaline and hydrazine hydrate in methanolic medium upon refluxing for $20 \mathrm{~min}$. The different Schiff's bases of 3-chloro-2hydrazinoquinoxaline were obtained by refluxing the appropriate substituted benzaldehydes and 3-chloro-2- hydrazinoquinoxaline in acetic acid medium for $2 \mathrm{~h}$. The obtained quinoxaline Schiff's bases were further converted into their derivatives by reacting the Schiff's bases with isoniazide in pyridine medium. All the compounds possess antibacterial activity ${ }^{43}$.
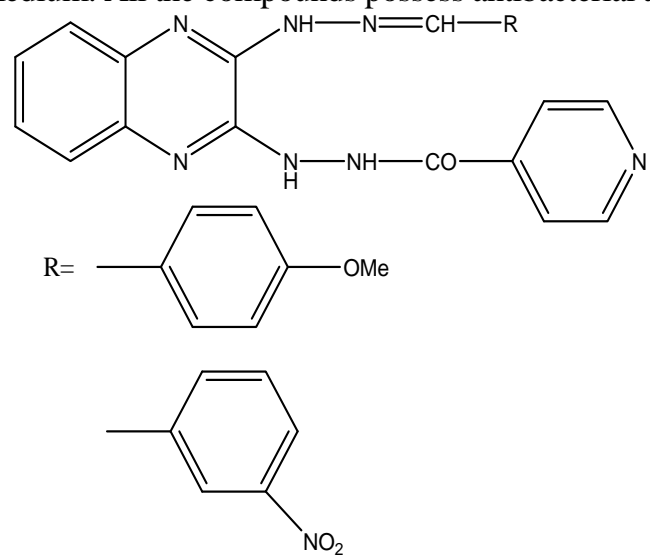

9) 2-Chloro-3-methylquinoxaline was selected as nucleus around which the molecular manipulations were carried out to get new compounds expected to possess better antimicrobial activity. Various quinoxaline derivatives have been synthesized by replacing the chlorine at $\mathrm{C}-2$ with a thioether linkage, which in turn attached to 2 -( $N$-(substituted phenyl) acetamides. The synthesized compounds were tested for their antimicrobial activity ${ }^{44}$.

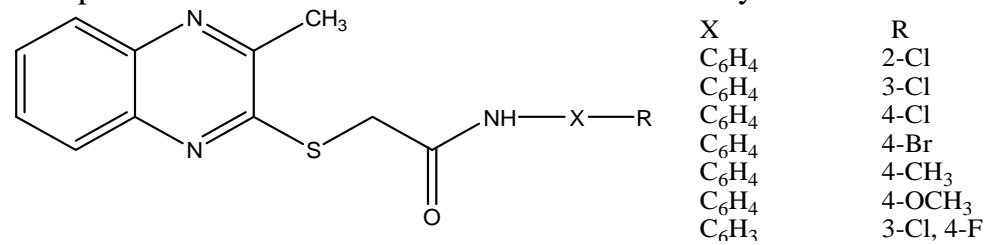

2-(2-methylquinoxaline-3-ylthio)- $N$-sub stitutedphenyl)acetamides

10) Substituted 3-benzylquinoxalines were synthesized from substituted phenyl pyruvic acid and $o$-phenylenediamine. All the compounds showed good antifungal activity ${ }^{45}$.<smiles>[R]C1C=CC(Cc2nc3ccccc3[nH]c2=O)CC1</smiles>

Substituted 3-benzylquinoxaline derivatives

11) Condensation of 4-benzoyl-1,2-phenylenediamine with sodium pyruvate in aceticacid furnished two products which were identified as 6-benzoyl and 7-benzoyl-3-methyl$2(1 H)$ quinoxalinones. Fusion of 6-benzoyl compound with aromatic aldehydes furnished the styryl derivatives. Alkylation of 6-benzoyl and 7-benzoyl-3-methyl-2(1H)quinoxalinones with dimethyl sulphate or ethyl chloroacetate produced the $\mathrm{N}$-alkyl derivatives. Hydrazinolysis of the 
ester derivative with hydrazinehydrate afforded the hydrazide hydrazinehydrate afforded the hydrazide derivative which underwent condensation with aldehydes to give the corresponding hydrazone derivatives. In addition, chlorination of 6-benzoyl compound with thionyl chloride afforded the 2-chloro derivative which was subjected to reaction with sodiumazide and nbutylamine to yield the corresponding tetrazolo and $n$-butylamino derivatives, the synthesized compounds were screened for antimicrobial activity ${ }^{46}$.

12) 1- $N$-(3’Methyl quinoxaline-2-yl-amino)4-aryl-3-chloro-2-azetinones has been synthesized for their antimicrobial activity ${ }^{47}$.<smiles>[R]C1C(Cl)C(=O)N1Nc1nc2ccccc2nc1C</smiles>

$\mathrm{R}=\mathrm{C}_{6} \mathrm{H}_{5}, 2 \mathrm{OHC}_{6} \mathrm{H}_{5}, 4 \mathrm{OHC}_{6} \mathrm{H}_{5}$, $2 \mathrm{ClC}_{6} \mathrm{H}_{5}, 2 \mathrm{NO}_{2} \mathrm{C}_{6} \mathrm{H}_{5}, \mathrm{CH}=\mathrm{CHC}_{6} \mathrm{H}_{5}$

13) Quinoxaline derivatives containing an oxadiazole moiety demonstrated marked antibacterial activity ${ }^{48}$.<smiles>O=c1[nH]c2ccccc2nc1/C(=N/Nc1ccc(Cl)cc1)c1nnco1</smiles>

\section{Conclusion}

$\mathrm{R}=\mathrm{H}, \mathrm{CH}_{3}$

The different type of quinoxaline derivatives are shows antimicrobial activity. The plethora of research described in this review indicates an antimicrobial activities exhibited by quinoxalines derivatives. The biological profiles of these new generations of quinoxalines would represent a fruitful matrix for further development of quinoxaline nucleus, which can be a lead nucleus for future developments to get safer and effective therapeutic agents.

\section{References}

1. http://en.wikipedia.org/wiki/Quinoxaline.

2 Badran M M, Abonzid K A and Hussein M H M, Arch Pharm Res., 2003, 26(2), 107-113; DOI:10.1007/BF02976653

3. Griffith R K, Chittur S V and Chen Y C, Med Chem Res., 1992, 2, 467-473.

4. El-Gendy A A, El-Meligie S, El-Ansry A and Ahmedy A M, Arch Pharm Res., 1995, 18(1), 44-47; DOI:10.1007/BF02976507

5. Reddy-Sastry C V, Shrinivas-Rao K, Krishanan V S H, Rastogi K, Narayanan G and Jain M L, Indian J Chem., 1990, 29B, 396-403.

6. $\quad$ El-Hawash S A, Habib N S and Fanaki N H, Pharmazie, 1999; 54(11), 808-815. 
7. Westphal G, Wasiki H, Zielinski U, Weberr F G, Tonew $\mathrm{M}$ and Tonew E, Pharmazie, 1977, 32, 570-571.

8. Monge A, Martinez-Crespo F J, Cerai A L, Palop J A, Narro S, Senador V, Marin A, Yolanda S, Mercedes G, Elizabeth H and Andy J B, J Med Chem., 1995, 38(22), 44884495; DOI:10.1021/jm00022a014

9. Michael J W, Taibi B H, Ann T K, Ramdani A, Touzani R, Elkadiri S, Hakkou A, Boukka M and Elli T, Molecule, 2002, 7, 641.

10. Rangisetty J B, Gupta C N V H B, Prasad A L, Srinivas P, Sridhar N, Parimoo P and Veeranjaneyulu A, J Pharm Pharmacol., 2001, 53(10), 1409-1413; DOI:10.1211/0022357011777765

11. Wagle S, Adhikari A V and Kumari N S, Indian J Chem., 2008, 47B, 439-448.

12. Ganapaty S, Ramalingam P and Rao C B, Indian J Heterocycl Chem., 2007, 16(3), 283-286.

13. Bailly C, Echepare S and Gago F, J Anti-cancer Drug Des., 1999, 15, 291.

14. Kovalenko M, Gazit A, Bohmer A, Ronnstrand L, Rorsman C, Heldin C H, Johannes Waltenberger, Frank D Böhmer and Alexander Levitzki, Cancer Res., 1994, 54(23), 6106-6114.

15. Miyata F, Yoshida S, Yamori T and Katoh T, Hetrocycles, 2001, 54(2), 619.

16. Barret R and Daudon M, Synth Comm., 1990, 20, 1543-1549; DOI:10.1080/00397919008052871

17. Moore S, Kondo M, Copeland M, Meienhofer J and Randall K J, J Med Chem., 1975, 18(11), 1098-1101; DOI:10.1021/jm00245a010

18. (a) Azaki K, Isono K and Okuma L J, Antibiot., 1981, 13; (b) Gerber N G and Lechevalier M P, Biochem., 1964, 3(4), 598-602; DOI:10.1021/bi00892a022

19. Igarashi Y, Takagi K, Kijura T, Furumai T and Oki T J, Antibiot., 1998, 51, 915.

20. Barton, John E D, Freeman and Peter F H, Ger Offen Brit Appl., 2, 029, 079; Chem Abst., 1971, 74, 99891.

21. Rainer A, Eur J Inorg Chem., 1965, 98(7), 2322-2326;

DOI:10.1002/cber.19650980735

22. Scriabine A, Ludden C T, Waston L S, Stavorski J M, Morgen G, Baldwin J J, Experientia, 1979, 35, 653.

23. Jain R, Agarwal D D and Dhamodharan, J Indian Chem Soc., 1995, 72, 825.

24. Shehata I A and Glenon R A, J Heterocycl Chem., 1987, 24(5), 1291-1295; DOI:10.1002/jhet.5570240511

25. Talley J J, US Appl. 473, 884, 1995. Chem Abst., 1999, 130, 110269.

26. Yadav D, Pandey S N, Kumar S and Sinha S, Int J Curr Pharm Rev Res., 2011, 1(3), 33-46.

27. Xiang-Hong Wu, Gang Liu, Jing Zhang, Zhan-Guo Wang, Song Xu, Suo-De

Zhang, Liang Zhang and Lin Wang, 2004, 8(2), 165-147;

DOI:10.1023/B:MODI.0000025639.89179.60

28. Rowe D J, Perfumer Flavorist., 1999, 24.

29. Otsuka H and Shoji J, Tetrahedron, 1967, 23, 1536.

30. Finar I L, Organic Chemistry, Pearson Education Limited, Ed., $5^{\text {th }}$, 2000, 634-635.

31. Schannk K and Lick C, Synthesis, 1983, 392.

32. Hoffmann R V, Kim H O and Wilson A L, J Org Chem., 1990, 55(9), 2820-2822; DOI:10.1021/jo00296a047

33. Bansal R K, Heterocyclic Chemistry. $3^{\text {rd }}$ Ed., New Age International Pvt. Ltd. 2005, 464-472.

34. http://www.thefullwiki.org/Quinoxalines 
35. Jones R G and McLaughlin K C, Org Synth., 1950, 30, 86.

36. Talari S, Govindarajan R, Karunakaram D, Jupudi S and Udhayavani S, Int J Pharm., 2013, 3(1), 145-151.

37. Srinivas M, Tejasri A, Anjaneyulu N and Satyanarayana K. Int J Pharma Sci., 2013, 3(1), 142-146.

38. Geethavani M, Raveendra Reddy J and Sathyanarayana S V, Int J Pharm Technol., 2012, 4(3), 4700-4710.

39. Castellanos J J M, Ramírez-Hernández K, Nancy S. Gómez-Flores, Oscar R RodasSuárez and Javier Peralta-Cruz, Molecules, 2012, 17, 5164-5176.

40. Ahoya Caleb, Daouda Ballo, Bouhfid Rachid, Hançali Amina, Bousmina Mostapha, Zerzouf Abdelfettah, El Aouad Rajae and Essassi El Mokhtar, Arkivoc., 2011; 217-226.

41 Mostafa A H, Bull Korean Chem Soc., 2011, 32(5), 1511-1518; DOI:10.5012/bkcs.2011.32.5.1511

42. Ratnadeep V Ghadage and Pramod J Shirote, J Chem Pharm Res., 2011, 3(5), 260-266.

43. Noorulla S M D, Sreenivasulu N, Khan A and Sayeed A, Heterocycles, 2011, 2(2-3), 229-238.

44. Singh D C P, Hashim S R and Singhal R G, J Chem., 2011, 8(2), 635-642;

DOI:10.1155/2011/482831

45. Devmurari V P and Jivani N P, Current Pharma Res., 2010, 1(1), 41-43

46. Ali M M, Ismail M M F, El-Gaby M S A, Zahran M A and Ammar Y A, Molecules, 2000, 5, 864-873; DOI:10.3390/50600864

47 Vyas D A, Chauhan N A and Parikh A R, J Chem., 2007, 46B, 1699-1702.

48 Kurasawa Y, Muramatsu M, Yamazaki K, Okamoto Y and Takado A, J Heterocycl Chem., 1986, 23(5), 1387-1390; DOI:10.1002/jhet.5570230526 